Iwona Dembicz, 1. Polska Akademia Nauk, Ogród Botaniczny - Centrum Zachowania Różnorodności Biologicznej w Powsinie, ul. Prawdziwka 2, 02-973 Warszawa, Polska, 2. Zaktad Ekologii Roślin i Ochrony Środowiska, Wydział Biologii, Instytut Botaniki, Uniwersytet Warszawski, ul. Żwirki i Wigury 101,02-089 Warszawa, Polska; e-mail: i.dembicz@gmail.com

ŁuKASZ KozuB, Zakład Ekologii Roślin i Ochrony Środowiska, Wydziat Biologii, Instytut Botaniki, Uniwersytet Warszawski, ul. Żwirki i Wigury 101, 02-089 Warszawa, Polska; e-mail: lukasz.kozub@biol.uw.edu.pl

Wptynęto: 11.10.2019 r.; przyjęto do druku: 03.12.2019 r.

DOI: https://doi.org/10.35535/ffgp-2019-0038

\title{
Nowe stanowisko Oenothera suaveolens (Onagraceae) na Wyżynie Śląskiej
}

Oenothera suaveolens Desf. ex Pers. jest rośliną dwuletnią zaliczaną do typowej serii Oenothera (sekcja Oenothera, podsekcja Oenothera; Onagraceae) (RosTAŃSKI 1985; WAGNER $i$ in. 2007; RostAŃSKI i in. 2010). Pochodzenie gatunku nie zostało jak dotąd jednoznacznie wyjaśnione (ROSTAŃSKI i in. 2010; TOKARSKA-GUZIK i in. 2012). W oparciu o dane cytogenetyczne ClELAND (1972) twierdził, że jest to gatunek pochodzenia mieszańcowego, powstały w Europie, najprawdopodobniej jako wynik krzyżowania $O$. biennis L. z którymś z gatunków amerykańskich. Niektórzy autorzy uważają, że jest to gatunek północnoamerykański (Minulka \& Pyšek 2001; Celesti-Grapow i in. 2009; Randall 2017), co budzi wątpliwości, ponieważ nigdy nie został zaobserwowany w Ameryce Północnej. Sytuację utrudnia fakt, że $O$. biennis (jeden z domniemanych gatunków rodzicielskich O. suaveolens) ma również niewyjaśnione pochodzenie (RosTAŃsKI i in. 2010). Niemniej jednak, bez względu na to czy $O$. suaveolens jest mieszańcem dwóch gatunków obcych, czy też mieszańcem między gatunkiem obcym a rodzimym w Europie, nie zmienia to faktu, że powinien być traktowany jako obcy składnik flory europejskiej, zgodnie z zaleceniami PYŠEK’A i in. (2004).

Morfologicznie Oenothera suaveolens najbardziej przypomina $O$. biennis, ma od niego jednak większe kwiaty oraz słabiej ogruczoloną strefę kwiatostanu. Pierwsze stanowisko tego gatunku w Europie zostało zarejestrowane w 1862 r. na Węgrzech (MiHULKA \& PYŠEK 2001). Od tego czasu gatunek został zaobserwowany również na terenie Portugalii, Hiszpanii, Francji, Belgii, Holandii, Danii, Szwecji, Niemiec, Szwajcarii, Austrii, Włoch, Albanii, Czarnogóry, Grecji, Słowacji, Czech, Polski, Mołdawii, Ukrainy, Łotwy oraz Rosji (Rostański i in. 2010; RAAB-Straube 2018).

W Polsce Oenothera suaveolens jest gatunkiem rzadkim, notowanym na kilkunastu stanowiskach w zachodniej części kraju (ZAJĄC \& ZAJAC 2001; RosTAŃSKI \& LATOWSKI 2010; WoŹNIAK-CHODACKA 2015). Uważany jest za kenofita (RostAŃSKI \& LATOwSKI 2010; TOKARSKA-GUZIK $\mathrm{i}$ in. 2012). Występuje na siedliskach antropogenicznych takich jak przydroża, tereny kolejowe, piaszczyste nieużytki, ugory (RosTAŃSKI \& LATOwSKI 
2010; WoŹNIAK-CHODACKA 2015). Najstarsze udokumentowane stanowisko O. suaveolens w Polsce pochodzi z 1882 r. z miejscowości Antonin w województwie wielkopolskim (ROSTAŃSKI \& LATOWSKI 2010).

Nowe stanowisko Oenothera suaveolens zostało odkryte w Zabrzu, w pobliżu ulicy Cmentarnej (50 $18,373^{\prime} \mathrm{N}, 18^{\circ} 48,208^{\prime} \mathrm{E} ; 265$ m n.p.m.), w południowej Polsce, 18 czerwca 2017 r. Zgodnie z metodą kartogramu ATPOL (ZAJĄC 1978; ZAJĄC \& ZAJĄC 2001), mieści się w jednostce DF31, gdzie dwie pierwsze litery oznaczają kwadrat o boku $100 \mathrm{~km}$, a dwie cyfry za nimi - kwadrat o boku $10 \mathrm{~km}$ (Ryc. 1). Jest to pierwsze udokumentowane stanowisko gatunku na Wyżynie Śląskiej. Kilkanaście osobników generatywnych O. suaveolens zaobserwowano na terenie ruderalnym, w pobliżu torów kolejowych, w środkowo-wschodniej części Zabrza. Teren ten pokryty był głównie roślinnością ruderalną z klasy Artemi-

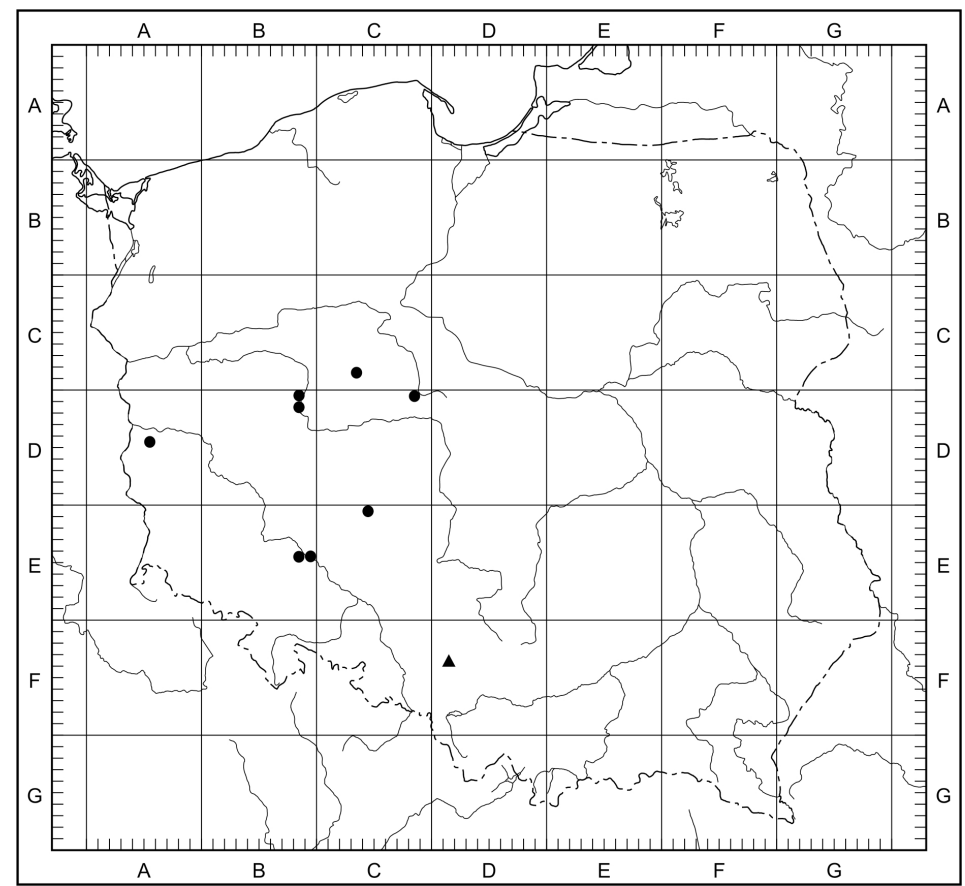

Ryc. 1. Rozmieszczenie Oenothera suaveolens w Polsce: • - znane stanowiska (ZAJĄC \& ZAJĄC 2001; RosTAŃSKI \& LATOWSKI 2010; WoźNIAK-CHODACKA 2015); $\boldsymbol{\Delta}$ - nowe stanowisko

Fig. 1. Distribution of Oenothera suaveolens in Poland: • - known localities (after ZAJĄC \& ZAJĄC 2001; ROSTAŃSKI \& LATOWSKI 2010; WoŹNIAK-CHODACKA 2015); $\boldsymbol{\Delta}$ - new locality

sietea vulgaris. Wśród gatunków towarzyszących zaobserwowano m.in. Artemisia vulgaris, Calamagrostis epigejos, Centaurea jacea, Chenopodium album, Convolvulus arvensis, Daucus carota, Erigeron annuus, E. canadensis, Poa compressa, Setaria viridis, Solidago gigantea, Tanacetum vulgare i Oenothera royfraseri. Warto zwrócić uwagę, iż O. royfraseri, choć znany na Wyżynie Śląskiej (ZAJAC \& ZAJĄC 2001; TOKARSKA-GUZIK 2015), jak dotąd nie był notowany w Zabrzu. 
Oenothera suaveolens nie przejawia aktualnie inwazyjności w Polsce (ToKARSKA-GuZIK $\mathrm{i}$ in. 2012), jednak w niektórych krajach europejskich takich jak Węgry i Włochy uznawany jest za inwazyjny (MinulKa \& PYŠEK 2001; Celesti-Grapow i in. 2009; Randall 2017 i cytowana tam literatura). Rozprzestrzenianie się gatunku w Polsce wymaga dalszych badań. Okazy zielnikowe O. suaveolens (leg. A. Pliszko, det. M. Woźniak-Chodacka) zostały zdeponowane w Zielniku Instytutu Botaniki im. W. Szafera Polskiej Akademii Nauk w Krakowie (KRAM).

Podziękowania. Praca została zrealizowana w ramach działalności statutowej Instytutu Botaniki im. W. Szafera Polskiej Akademii Nauk oraz przy udziale środków finansowych Instytutu Botaniki Uniwersytetu Jagiellońskiego w Krakowie (K/ZDS/007344).

Summary. New locality of Oenothera suaveolens (Onagraceae) in the Silesian Upland. The paper gives a new record of Oenothera suaveolens and presents its distribution in Poland, using the ATPOL cartogram method (Fig. 1). It was found in 2017 on ruderal ground near the railway track in Zabrze (Silesian Upland, S Poland). The spread of this established alien species in Poland needs to be intensively studied.

\section{LITERATURA}

Celesti-Grapow L., Alessandrini A., Arrigoni V., Banfi E., Bernardo L., Bovio M., Brundu G., Cagiotti M. R., Camarda I., Carli E., Conti F., Fascetti S., Galasso G., Gubellini L., La Valva V., Lucchese F., Prosser F., Siniscalco C., Villani M. C., Viegi L., Wilhalm T. \& Blasi C. 2009. Inventory of the non-native flora of Italy. - Plant Biosystems 143(2): 386-430.

Cleland R. E. 1972. Oenothera cytogenetics and evolution. s. 370. Academic Press, London and New York.

MinULKA S. \& PYšEK P. 2001. Invasion history of Oenothera congeners in Europe: a comparative study of spreading rates in the last 200 years. - Journal of Biogeography 28: 597-609.

Pyšek P., Richardson D. M., Rejmánek M., Webster G. L., Williamson M. \& Kirschner J. 2004. Alien plants in checklists and floras: towards better communication between taxonomists and ecologists. - Taxon 53: 131-143.

RAab-Straube E. von 2018. Onagraceae. - W: Euro+Med Plantbase - the information resource for Euro+Mediterranean plant diversity. http://ww2.bgbm.org (dostęp: 02.11.2018).

Randall R. P. 2017. A global compendium of weeds. $3^{\text {rd }}$ edition. s. 3654. Randall R. P., Perth, Western Australia.

Rostański K. 1985. Zur Gliederung der Subsektion Oenothera (Sektion Oenothera, Oenothera L., Onagraceae). - Feddes Repertorium 96(1-2): 3-14.

RostańsKi K. \& LAtowsKi K. 2010. Rodzaj Oenothera (Onagraceae) na Nizinie Wielkopolsko-Kujawskiej. - Fragmenta Floristica et Geobotanica Polonica 17(1): 43-57.

Rostański K., Rostański A., Gerold-Śmietańska I. \& Wassowicz P. 2010. Wiesiołki (Oenothera) występujące w Europie. s. 157. Instytut Botaniki im. W. Szafera, Polska Akademia Nauk, Katowice - Kraków.

TOKARSKA-GuZIK B. 2015. Oenothera royfraseri R. R. Gates. - W: A. ZAJĄC \& M. ZAJĄC (red.), Rozmieszczenie kenofitów w Karpatach polskich i na ich przedpolu, s. 134-135. Nakładem Instytutu Botaniki Uniwersytetu Jagiellońskiego, Kraków.

Tokarska-GuZik B., Dajdok Z., Zając M., Zając A., Urbisz A., Danielewicz W. \& HoŁdyński C. 2012. Rośliny obcego pochodzenia w Polsce ze szczególnym uwzględnieniem gatunków inwazyjnych. s. 197. Generalna Dyrekcja Ochrony Środowiska, Warszawa. 
Wagner W. L., Hoch P. C. \& Raven P. H. 2007. Revised classification of the Onagraceae. - Systematic Botany Monographs 83: 1-240.

WOŹNIAK-CHODACKA M. 2015. Nowe stanowiska rzadkich gatunków wiesiołków (Oenothera L.) na Dolnym Śląsku. - Acta Botanica Silesiaca 11: 141-148.

ZAJĄC A. 1978. Założenia metodyczne „Atlasu rozmieszczenia roślin naczyniowych w Polsce”. - Wiadomości Botaniczne 22(3): 145-155.

ZAJĄC A. \& ZAJĄC M. (red.). 2001. Atlas rozmieszczenia roślin naczyniowych w Polsce. s. xii + 714. Nakładem Pracowni Chorologii Komputerowej Instytutu Botaniki Uniwersytetu Jagiellońskiego, Kraków.

MoniKa WoźNIAK-ChodacKA, Zakład Roślin Naczyniowych, Instytut Botaniki im. Wtadystawa Szafera Polskiej Akademii Nauk, ul. Lubicz.46, 31-512 Kraków, Polska; e-mail: m.chodacka@ botany.pl

Artur PliszKo, Zaktad Taksonomii, Fitogeografii i Paleobotaniki, Instytut Botaniki, Uniwersytet Jagielloński, ul. Gronostajowa 3, 30-387 Kraków, Polska; e-mail: artur.pliszko@uj.edu.pl

Wptynęto: 07.12.2018 r.; przyjęto do druku: 24.06.2019 r.

DOI: https://doi.org/10.35535/ffgp-2019-0039

\section{Draba nemorosa (Brassicaceae) w południowo-zachodniej części Gór Świętokrzyskich}

Draba nemorosa L. (głodek żółty) reprezentuje podelement cyrkumborealny. Swoim zasięgiem obejmuje rozległe obszary Europy (głównie jej południowo-wschodnią część), Azji i Ameryki Północnej. Stanowiska z Polski leżą poza zwartym zasięgiem gatunku. Zlokalizowane są one przede wszystkim we wschodniej, południowo-wschodniej i centralnej części kraju. W ostatnich latach głodka żółtego potwierdzono m.in. na północnym-wschodzie i wschodzie (Pojezierze Litewskie, Wysoczyzna Białostocka, Wzgórza Sekólskie, Podlaski Przełom Bugu), na zachodzie (Pojezierze Gnieźnieńskie - gdzie występuje najliczniej, Równina Inowrocławska), w centrum i na południu Polski (Przedgórze Iłżeckie, Niecka Nidziańska, Kotlina Sandomierska, Wyżyna Krakowsko-Częstochowska oraz Karpaty) (Hultén \& Fries 1986; ZajĄC \& ZAJĄC 2001, 2009; ChMiEl 2014). Ostatnio gatunek odnaleziono w południowo-zachodniej części Gór Świętokrzyskich (ŁAZARSKI 2019).

Na obszarach niżowych Draba nemorosa występuje w zbiorowiskach półnaturalnych, najczęściej w murawach kserotermicznych z klasy Festuco-Brometea, rzadziej na pastwiskach, suchych łąkach i murawach napiaskowych. Zajmuje także siedliska antropogeniczne: wały przeciwpowodziowe, nasypy kolejowe, a nawet pola uprawne (CHMIEL 2014).

Głodek żółty jest narażony na wyginięcie w skali kraju, ale też regionalnie, np. w Wielkopolsce (JACKOWIAK i in. 2007; CHMIEL 2014; KAŹMIERCZAKOWA i in. 2016). Gatunek ten ma nieokreślony stopień zagrożenia (kategoria DD) na „czerwonej liście” Wyżyny Małopolskiej oraz Lubelszczyzny, co wskazuje na konieczność uzupełnienia danych o jego rozmieszczeniu w tych regionach (BRóż \& PRZEMYSKI 2009; CWENER i in. 2016). 